\title{
THE 'UNFORGETTABLE' EXPERIENCE OF FOREIGN LANGUAGE ANXIETY
}

\author{
Morana Drakulić \\ Faculty of Teacher Education, University of Rijeka, \\ Sveučilišna avenija 6, Rijeka, Croatia \\ E-mail address: morana@ufri.hr
}

(a) $\Theta \Theta \Theta$

\begin{abstract}
Foreign language anxiety (FLA) has long been recognized as a factor that hinders the process of foreign language learning at all levels. Among numerous FLA sources identified in the literature, language classroom seems to be of particular interest and significance, especially in the formal language learning context, where the course and the teacher are often the only representatives of language. The main purpose of the study is to determine the presence and potential sources of foreign language anxiety among first year university students and to explore how high anxiety levels shape and affect students' foreign language learning experience. In the study both the questionnaire and the interviews were used as the data collection methods. Thematic analysis of the interviews and descriptive statistics suggest that most anxiety-provoking situations stem from the language classroom itself.
\end{abstract}

Keywords: foreign language anxiety, language classroom, subjective experience, teacher

\section{INTRODUCTION}

My personal interest in the affective component of foreign language learning, namely foreign language anxiety, appeared when I started working as an elementary foreign language teacher eight years ago. First generation that I taught ( 3 grades of 14 year olds) was in the very last year of their compulsory education and had negative experiences from the previous years of language learning. The 'hostile', unmotivated atmosphere that was present in those classes was attributed to, what I than called, aversion to English language. What I soon realized was that it was more important to teach those students how to acquire the love for the language than how to acquire the language itself.

For the past five years I have been holding ESP classes to first year university students. As a young researcher with the aforementioned field of interest, I have been trying to create a low-anxiety classroom atmosphere. Despite my efforts to create a welcoming, warm and relaxing classroom environment, the present generation has proven to be very reluctant to be involved in any forms of oral performance. When asked if they felt uncomfortable or even afraid of my potential reaction to or the consequences of their eventual mistakes they answered negatively, but still, to a great extent, 'refused' to take part in conversations. This served as an 
incentive to investigate my students' past foreign language learning experiences and see whether they affected their present foreign language study.

\section{FOREIGN LANGUAGE ANXIETY - DEFINITION, SOURCES AND EFFECTS}

Foreign language anxiety can be defined 'as apprehension experienced when a situation requires the use of a second language ${ }^{27}$ with which the individual is not fully proficient' (Gardner, \& MacIntyre, 1993, p.5). It is, in other words, 'a tendency of an individual to react in a nervous manner when speaking, listening, reading or writing in the second language' (Gardner, \& MacIntyre, 1993, p.5).

Theoretical framework which first defined FLA as a separable construct in language learning was presented by Elaine Horwitz, Michael Horwitz and Joan Cope (1986). Drawing on the work of Thomas Scovel (1978) and Robert Gardner (1986) the authors propose that FLA is situation-specific type of anxiety, arising from the uniqueness of language learning situation and, thus, cannot be viewed as a manifestation of general anxieties.

The literature identifies many different sources of FLA. The most common, tripartite model, offered by Horwitz, Horwitz and Cope (1986), suggests that this individual difference variable stems from three general anxieties:

- communication apprehension which emerges from students' limited proficiency;

- test anxiety, which refers to negative reactions in testing situations;

- fear of negative evaluation i.e. the fear of being negatively evaluated by others.

We must emphasize that, although constructed of three general anxieties, FLA should not be viewed merely as the sum of the three but in the context of the language classroom variables which, to a great extent, shape this situational-specific type of anxiety.

Based on a review of the relevant literature, Jessica Young (1991) has identified six potential sources of FLA from three different aspects: the learner, the teacher and the instructional practice. These are: 1) personal and interpersonal anxieties; 2) learner beliefs about language learning; 3) instructor beliefs about language learning; 4) instructor-learner interactions; 5) classroom activities and 6) language testing. Empirically based classification was offered by Jelena Mihaljević Djigunović (2002). Drawing on the findings of an extensive study conducted on 392 students of various age, the author classified the sources of FLA among Croatian learners into ten categories listed according to their relevance: 1) language use in the classroom; 2) evaluation/testing; 3) negative self-perception; 4) the peculiarities of English language; 5) the use of language outside the classroom; 6) errors; 7) teacher; 8) general anxiety; 9) comprehension problems and 10) objective circumstances.

27 The term 'second language' is mostly used by Canadian and American researchers, but in European context it is often substituted with the term 'foreign language'. 
The identification of the sources of FLA is the first step towards defining and identifying the effects it has on the learner. Since 1980s, the research in this area has taken two basic directions -first tended to identify how FLA affects the academic performance whilst the other investigates the relation between language anxiety and cognitive processing.

Within the formal classroom settings, FLA has often been closely connected with poor achievement. In her early study, E. Horwitz (1986) found significant negative correlation between FLA and achievement among French and Spanish students. Similar results were found by E. Phillips (1992) whose research revealed the debilitating effect of FLA on oral test performance among college students, as well as by Y. Aida (1994) who found negative correlation between FLCAS scores and students' final grades.

The majority of research on FLA has been conducted on either high school or university students. The reason for this may lie in the assumption held by some researchers that foreign language anxiety is more relevant to language learning among adults (MacIntyre \& Gardner, 1991). However, despite the relatively small number of papers, the research on FLA among younger learners indicates the opposite. Daniel Yu-ching Chan and Guo-cheng Wu's (2004) research findings indicate the presence of certain level of anxiety among primary students in Taiwan. The FLCAS results revealed many different sources of FLA, which were categorized by the authors in five groups: low proficiency, fear of negative evaluation, competition of games, anxious personality and pressures from students and parents. These results were, to a certain extent, replicated by H. Liu and T. Chen (2013), whose sources of language anxiety among Taiwanese elementary school students were also in close relation with instructional practice, the teacher or the learner himself. The analysis of variance furthermore revealed that students with positive attitudes towards learning had significantly lower levels of FLA in comparison with students who held low- and mid-level positive attitudes. Another study by Sila Ay (2010) reveals that FLA levels may vary across different instructional levels in relation to language skills. The results suggest that listening and reading activities were found to be the most stressful among fifth graders, while speaking and writing exercises exhibited the highest levels of language anxiety among seventh grade students. All students, regardless the grade, held nearly the same degree of anxiety in relation to grammar. Diana Hasan's (1998) extensive study, conducted on 14 to 16 year old students, gave a closer insight into the nature of relationship between students' language anxiety, their perception of teacher's class behavior and students' achievement. The participants completed FLCAS as well as student-reported Teacher Style Scale (TSS) at the beginning and in the middle of the semester. The comparison of the results obtained by the two questionnaires revealed negative correlations between the variables. Students with positive perceptions of teacher class behavior had lower levels of anxiety and higher achievement unlike their colleagues who perceived teacher's behavior negatively and, thus, had higher levels of anxiety and lower achievement.

Students' perceptions of overall language classroom setting has proven to be a valuable source of information on how classroom variables may affect both cognitive and affective variables of foreign language acquisition (Drakulić, 2013; Mihaljević, 1991). The most detailed description on how certain language classroom 
factors, as perceived by students, may contribute to anxiety was offered by Renée Wörde (2003) and Mary L. Price (1991). R. Wörde identified numerous sources of foreign FLA that were grouped in five categories: 1) pedagogical and instructional practices; 2) speaking activities; 3) pedagogical and instructional practices; 4) error correction and 5) native speakers. The most disturbing finding was, as the author pointed out, the astonishing number of negative comments regarding teachers that were related to either their teaching techniques or personality. Similar findings were obtained by Mary L. Price (1991), whose participants had also reported the teacher as a main source of their anxiety in the language class.

The results of the abovementioned studies clearly indicate that FLA impedes language acquisition on both cognitive and affective level. There is, however, an ongoing debate whether the language anxiety is the cause or the effect of the poor language achievement (Sparks \& Granschow, 1991, 1993; MacIntyre, 1995). Since the body of the research is still correlational in nature, we cannot with certainty claim that FLA is the cause or the consequence of poor achievement. Additional experimental research in this field would for sure contribute to the clarification of this ongoing debate.

\section{METHODOLOGY}

The aims of the study were the following:

- to determine the presence and potential sources of FLA among the first year university students

- to explore how high anxiety levels shape and affect students' foreign language learning experience

The participants in this study were non-language university students enrolled in first year of study at the Faculty of Teacher Education in Rijeka, Croatia. A total of 69 students participated in this study.

Foreign language anxiety was measured by Foreign Language Classroom Anxiety Scale (FLCAS) developed by E. Horwitz, M. Horwitz and J. Cope (1986). We used Croatian version of the questionnaire (Mihaljević Djigunović, 2002). With possible scores ranging from 33 to 165, the criteria for establishing language anxiety according to the FLCAS are:

- less than 76 points - low anxiety

- 76-119 points - moderate anxiety

- $\quad$ more than 119 points - high anxiety

The qualitative part of the research included an interview which contained questions that were developed to elicit students' perceptions of their past learning experiences in relation to FLA. Interviews were also conducted in Croatian. We addressed the following questions in the study:

1. How did you feel in your foreign language classes?

2. What bothered you the most?

3. Which activities were the most stressful to you and why?

4. What role did the teacher play?

5. What could, in your opinion, have made foreign language classes more pleasant and less stressful? 
At the very beginning, the researcher explained students that the participation in this study was voluntary and anonymous and that the results would not in any way affect their final course grade. The students were also acquainted with the overall study procedure. Students were asked to fill in the questionnaire on the basis of their elementary school and secondary school foreign language learning experience.

Students first filled out the Croatian version of the FLCAS. On the basis of the results obtained in the questionnaire, students with the highest levels of FLA were scheduled for an interview. Each interview lasted approximately 15 minutes and was recorded with the subject's permission.

The analysis of the qualitative data included thematic analysis (Braun \& Clarke, 2012). First step was the transcription of the audio materials which served as the basis for further analysis. Data analysis included two operational steps: first reading and coding. During coding, and in line with research aims, we were trying to find sources of foreign language anxiety and explore the nature of the relationship between language anxiety and language learning experience.

\section{RESULTS}

The FLA level for each student was obtained by adding up the scores for items on a Likert scale. The scores on nine items (items 2, 5, 8, 11, 14, 18, 22, 28, and 32) were key-reversed before scoring. We present the descriptive results analysis in the table below:

\begin{tabular}{|l|c|c|}
\hline & $\mathbf{N}$ & $\mathbf{\%}$ \\
\hline low anxiety $(<76)$ & 20 & $29 \%$ \\
\hline moderate anxiety $(76-119)$ & 44 & $63,8 \%$ \\
\hline high anxiety $(<119)$ & 5 & $7,2 \%$ \\
\hline
\end{tabular}

Tab.1. The overall FLCAS scores

Source: Own research.

Six students who had high level of foreign language anxiety were invited to the interview. One student, whose score on FLCAS was 118, was also called to participate. Only one student did not respond to the interview request. Their scores were:

\begin{tabular}{|l|c|}
\hline \multicolumn{1}{|c|}{ student } & FLCAS score \\
\hline Student 1 - Iva & 147 \\
\hline Student 2 - Ana & 125 \\
\hline Student 3 - Mia & 124 \\
\hline Student 4 - Lea & 121 \\
\hline Student 5 - Bea & 120 \\
\hline Student 6 - Lana & 118 \\
\hline
\end{tabular}

Tab.2. FLCAS scores of highly anxious students Source: Own research. 
The coding of interview transcripts revealed several sources of foreign language anxiety: the teacher, error correction, fear of negative evaluation, low proficiency, the lack of discipline in class and test anxiety.

\section{INTERVIEWS}

All students who participated in the interview were eager to talk and share their experiences. At the very beginning they showed some signs of discomfort and nervousness, but as the interview progressed, they felt more relaxed and willing to talk about the issues that bothered them the most. We present parts of the interviews that we find to be particularly interesting ${ }^{28}$ :

Iva: I had been learning English in elementary school for less than one year after which my mother decided to withdraw me from the course because the teacher treated me horribly...treated only me horribly. I did not do anything wrong, but everything that went wrong during the classes was my fault...She sometimes made fun of how I spoke. English course was a very big burden to me. I did try and had lots of will, but (...) It was good in secondary school. My teacher was nice. I think that if my elementary school teacher had been nicer to me, I would not have had any problems with English today. I had the will but since then I have not even thought of learning it again. I sometimes regret for not trying and all of that but...I do not know.

Bea: It was awful in secondary school. It was so boring. We had a textbook we read the text, answered the questions and that was it! Every lesson the same thing. There were no additional materials, nothing, just that textbook...read it, answer it, read it, answer it - and that's it! The most uncomfortable activity for me was reading because she was correcting you even before you read the word. You get the feeling like you do not know English when she corrects you in that way...or reads instead of you. I felt uncomfortable when I made a mistake during reading - not because of the others but because of the teacher. She would always go like: "How come you do not know this?".

Lana: We did absolutely nothing in secondary school. All knowledge that I gained was from elementary school and movies and things like that. And this is the reason, I think, why I feel anxious now. There were lots of students in my class, you know... and if teachers did not define boundaries, we engaged in tomfoolery. In our class, the teacher could not get a word in...she did not know how to fight against it. I did not like that atmosphere because I knew that I would need it and wanted to learn it (...) I feel uncertain because I am aware I do not possess the knowledge that I should possess. I do not blame the teacher. Maybe I should have tried harder.

Lea: In secondary school, the last two lessons were always English lessons. Everybody was tired and restless. The teacher could not appease the class, it was horrible. So we were unable to do anything... we learned almost nothing. We had that textbook but have not done half of it. I felt uncomfortable during written exams. There was grammar that we did not cover very well and we did not under-

28 The names of the students were changed to protect their privacy. 
stand it. I was always afraid I would fail it. Oral exams were OK, but there were not many of them. I underwent two oral exams in four years. (...) The teacher did not specifically cause my anxiety. I think that everything...the whole situation did. She did try but did not have any chance because of the whole atmosphere in the class.

\section{DISCUSSION}

All of the students that took part in the interview had, at some point of their education, negative experiences in foreign language learning. Most of them, however, pointed out that they were quite satisfied with their elementary school language classes, whereas secondary school experiences were quite disturbing and made a strong impression on them.

None of the students believed they were the potential sources of FLA. They all reported they loved languages, were interested in the subject and were motivated for learning. However, stressful classroom experiences during secondary education had a debilitating effect on their initial motivation and positive attitudes. It seems that the lack of discipline which, in turn, affected the quality of classes and was perceived as the main source of low proficiency, bothered students the most. They were all aware they would need the knowledge of English language in their future education and in life. In fact, the very awareness of the lack of their present knowledge made them feel uncomfortable and insecure when they had to engage in any kinds of activities or during evaluative situations.

Activities that students found most stressful were written and oral exams. This finding is not surprising, since plethora of research has indicated that test anxiety has significant effect on the foreign language learning process. Two students believed they did not know the subject matter well enough and the notion of failing the written exam prevented them from concentrating more closely on the tasks given. Another student said her hastiness was the cause of many mistakes she had made in tests, which resulted in the student's frustration. This student preferred oral exams because of the possibility of correcting the mistakes she was making during speaking. While anxiety during written exams may have been related to sources such as negative self-perception and poor comprehension, anxiety experienced during oral examinations stemmed from the fear of being negatively evaluated by others. In this connection, some students were worried that other classmates would laugh at them while the others were more concerned with the teacher's reaction which they evaluated as inappropriate and embarrassing.

This brings us to the role of the teacher in the amount of students' FLA. One student reported she did not like to read aloud because the teacher's reaction to her mistakes was always very unpleasant and humiliating. Still, the most intriguing experience described during the interviews was Iva's experience. This student's stressful classroom experience was, as she perceived it, directly connected with the teacher who, as she said, treated her horribly. The teacher made fun of her accent and blamed her for indiscipline in class she had never initiated. Iva said she 
generally felt uncomfortable in her presence. During any kinds of oral activities, the teacher constantly criticized her accent which eventually resulted in her giving up the conversation in foreign language. Iva eventually dropped from the course on which she spent less than a year. This student explained that she was highly motivated for learning English language before she enrolled the course, but constant mistreatment by her teacher not only made her give up learning at the time, but created some sort of aversion towards English in the future as well.

Although only one interview question directly addressed the role of the instructor, throughout all five interviews, the prevailing topic was the teacher. All students, to a great extent, emphasized and described, the same causal ${ }^{29}$ relations $^{2}$ that were happening in their language classrooms. The core of the problem was, as perceived by these students, low-quality classes in which the content was either not presented or it was presented in an inadequate way. This resulted inadequate knowledge, which in turn, in their case, gave rise to insecurity, discomfort and, eventually, foreign language anxiety.

\section{CONCLUSION}

The results obtained in this study revealed several sources of foreign language anxiety, among which, according to the students' perceptions, the most prominent are the teacher, error correction, fear of negative evaluation, low proficiency, the lack of discipline and test anxiety.

Classroom experiences described by students enrolled in this study indicate that classroom variables may facilitate foreign language anxiety. It is very indicative that all students said they were motivated at the beginning of their language study, but negative experiences during secondary and, in Iva's case, primary school left a stronger 'impression'. Students seem to believe that poor language classes in which 'nothing has been done' are the primary source of their poor knowledge and, ultimately, achievement. Great emphasis here was put on the teacher's role but, paradoxically, none of the students, except for Iva, perceived their language teacher as a threat but as the victim of circumstances which they could not and did not know how to control.

The sample included in this study was not representative and general conclusions should not be drawn based on a collected data. Moreover, students' insights only are not sufficient source of information - additional research on other students' individual difference variables would greatly contribute to a more complete understanding of this complex phenomenon.

Nevertheless, these students' perceptions seem to go in favor of the claim that FLA is equally relevant to language learning among children, adolescents and adults and that early negative experiences may affect the quality of further language acquisition.

29 By this term we do not implicate any causal relationships between the variables in questions, but describe students' perceptions of foreign language classroom setting. 


\section{REFERENCES}

Aida, Y. (1994). Examination of Horwitz, Horwitz and Cope's Construct of Foreign Language Anxiety: The Case of Students of Japanese. Modern Language Journal, 78(2), 155-168.

Ay, S. (2010). Young Adolescent Students' Foreign Language Anxiety in Relation to Language Skills at Different Levels. The Journal of International Social Research, 3(11), 83-91.

Braun, V., Clarke, V. (2012). Thematic analysis. In Cooper, H. (Ed.), The Handbook of Research Methods in Psychology. Washington, DC: American Psychological Association.

Chan, D.Y., Wu, G. (2004). A Study of Foreign Language Anxiety of EFL Elementary School Students in Taipei County. Journal of National Taipei Teachers College, 17(2), 287-320.

Drakulić, M. (2013). Foreign Language Teacher Competences as Perceived by English Language and Literature Students. Journal of Education Culture and Society, 1, 158-165.

Gardner, R.C. (1986). Social Psychology and Second Language Learning: The Role of Attitudes and Motivation. Town: Edward Arnold.

Gardner, R.C., MacIntyre, P.D. (1993). A Students' Contribution to Second Language Learning. Part two: Affective Variables. Language Teaching, 26(1), 1-11.

Hasan, D.C. (1998). An Exploration of Interrelationships among Students' Foreign Language Anxiety, Their Perception on Teachers' Classroom behaviour and Students' Achievement in Learning English as a Foreign Language. Paper presented at the AARE Annual Conference, Adelaide.

Horwitz, E.K. (1986). Preliminary Evidence for the Reliability and Validity of a Foreign Language Anxiety Scale. TESOL Quarterly, 20(3), 559-562.

Horwitz, E.K., Hortwitz, M.B., Cope, J.A. (1986). Foreign Language Classroom Anxiety. The Modern Language Journal, 79(1), 125-132.

Liu, H., Chen, T. (2013). Foreign Language Anxiety in Young Learners: How It Relates to Multiple Intelligences, Learner Attitudes, and Perceived Competence. Journal of Language Teaching and Research, 4(5), 932-938.

MacIntyre, P.D. (1995).How Does Anxiety Affect Second Language Learning? A Reply to Sparks and Ganschow. TheModern Language Journal,79(1), 90-99.

MacIntyre, P.D., Gardner, R.C. (1991). Methods and Results in the Study of Anxiety and Language Learning: A Review of the Literature. Language Learning, 41(1), 85-117.

Mihaljevic, J. (1991). Attitudes Towards the Teacher as a Factor in Foreign Language Learning. Studia Romanica et Anglica Zagrabienensia, 36-37, 143-152.

Mihaljević Djigunovic, J.(2002). Strah od stranog jezika: kako nastaje, kako se očituje i kako ga se osloboditi [Foreign language anxiety: how it originates, how it manifests and how to get rid of it]. Zagreb: Naklada Ljevak.

Phillips, E.M. (1992).The Effects of Language Anxiety on Students' Oral Test Performance and Attitudes. The Modern Language Journal, 76(1), 14-26.

Price, M.L. (1991).The Subjective Experience of Foreign Language Anxiety: Interviews With Highly Anxious Students. In: E. K. Horwitz, D. J. Young (Eds.), Language Anxiety: From Theory and Research to Classroom Implications(pp. 101-108). Englewood Cliffs, NJ: Prentice Hall.

Scovel, T. (1978). The Effect of Affect on Foreign Language Learning: A Review of the Anxiety Research. Language Learning, 28(1), 129-142.

Sparks, R.L., Granschow, L. (1991).Foreign Language Learning Differences: Affective or Native Language Aptitude Differences? The Modern Language Journal, 75(1), 3-16.

Sparks, R.L., Granschow, L. (1993).The Impact Of Native Language Learning Problems on Foreign Language Learning: Case Study Illustrations of the Linguistic Coding Deficit Hypothesis. The Modern Language Journal, 77, 58-74.

Wörde,v. R. (2003). Students' Persepective on Foreign Language Anxiety. Inquiry, 8(1), 1-15.

Young, D.J. (1991). Creating a Low-Anxiety Classroom Environment: What Does Language Anxiety Research Suggest? The Modern Language Journal, 75(4), 426-437. 